\title{
Some peltigericolous microlichens from southern Poland
}

\author{
Pawel CZARnota*, Emil Hernik \\ Department of Agroecology, University of Rzeszów, Ćwiklińskiej 2, \\ 35-601 Rzeszów, Poland
}

\begin{abstract}
Ten microlichens growing on more or less moribund thalli of several terricolous Peltigera spp. are reported from Wyżyna Śląsko-Krakowska upland in southern Poland. The list includes: Absconditella delutula, Agonimia vouauxii, Bacidia pycnidiata (for the first time as a lichenicolous lichen), Bacidina chloroticula, Placynthiella dasea, Scutula sp., Steinia geophana, Thelocarpon epibolum, Vezdaea aestivalis and V. retigera. Notes on the taxonomy, ecology and distribution of each species are briefly provided and Polish samples discussed.
\end{abstract}

Keywords: Ascomycota, ecology, lichenized fungi, lichenicolous lichens, post-industrial region

\section{Introduction}

Lichenicolus fungi growing on representatives of the genus Peltigera were investigated many times (e.g. Alstrup and HaWKSWORTH 1990, KüMMERLING and Alstrup 1992, MiĄDliKowsKa and Alstrup 1995, Hawksworth and MiąDLIKOWsKa 1997, MartíneZ and Hafellner 1998, Martínez 1999, Kocourková 2000, Czyżewska and KuKwa 2009, CAndan et al. 2010, PuolasmaA et al. 2012). The genus Peltigera, with members usually forming large lichen thalli with cyanobacteria (e.g. Nostoc spp.), is widely considered one of these lichen hosts that are inhabited by the highest number of fungal specialists (HAwKSWORTH and MiąDLIKOWSKA 1997). Data on lichenicolous lichens and 'four-biont symbioses' are rare (Hawksworth 1988, Czarnota 2009). In Poland lichenicolous lichens are still insufficiently known, but recently some of them have been included within the national list of lichenicolous fungi (CZYŻEWSKA and KUKWA 2009).

\section{Study area}

Materials were collected in 2004-2005 by the second author in the three geographical mesoregions of the Wyżyna Śląsko-Krakowska upland $\left(2,615 \mathrm{~km}^{2}\right)$ in southern Poland, the

* Corresponding author, e-mail: pawczarnota@poczta.onet.pl

Copyright ${ }^{\circledR} 2014$ by Acta Botanica Croatica, the Faculty of Science, University of Zagreb. All rights reserved. 
Wyżyna Częstochowska upland, the Obniżenie Górnej Warty depression and the Garb Tarnogórski hummock (Fig. 1; KONDRACKI 2000). The three mesoregions are different from geomorphological, hydrological and floral points of view, and they also differ in the level of anthropogenic impact. Various types of limestones dominate there, sometimes appearing above the ground as big outcrops often covered by xerothermic plants (URBISZ 2004), and several endemic vascular plants including Galium cracoviense Ehrend. (MIREK 2001), Potentilla silesiaca Uechtr. (KOŁODZIEJEK 2001a), Cochlearia polonica Fröhlich (KWIATKOWSKA 2001) can be found there. The lichen-forming fungus Verrucaria polonica Nowak (NOWAK 1959) was described from its locus classicus the Wyżyna Śląsko-Krakowska upland. In the Obniżenie Górnej Warty depression there are different natural metal-enriched habitats and post-mining iron wastes to be found. Because of the former mining activity there are a lot of local small elevations and depressions covered by post-ruderal grasslands and plant communities of wet habitats (KoŁODZIEJEK 2001b).

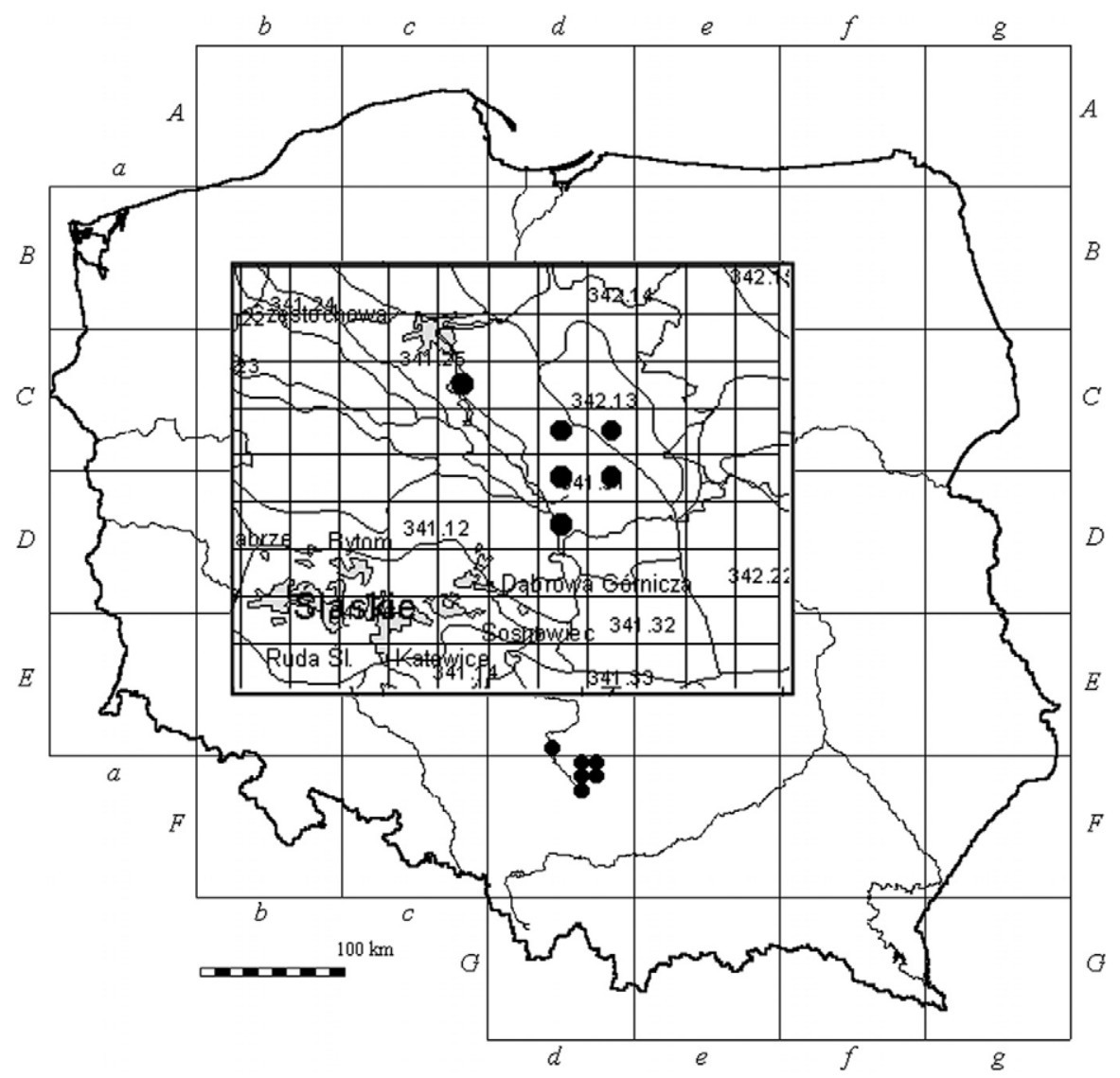

Fig. 1. Localities of examined peltigericolous lichens based on Atpol grid square system and geographical mesoregions of Poland. Abbreviations of mesoregions: 341.12 - Garb Tarnogórski plateau, 341.31 - Wyżyna Częstochowska upland, 341.25 - Obniżenie Górnej Warty depression. 


\section{Materials and methods}

Collected material was investigated by standard microscopy. Hand-made sections of ascocarps and pycnidia mounted in water were prepared for detailed examination of their internal pigmentation and dimensions of anatomical characters. Sometimes internal tissues were mounted in $\mathrm{HNO}_{3}$ or $\mathrm{KOH}$ for better recognition of the spore septation and the separation of particular structures. Habits, internal characters of fruit-bodies and some hamathecial features of noteworthy species have been photographed (Figs. 2-3). Nomenclature of lichenized fungi follows Index Fungorum (date of searching March 12, 2013). Examined specimens are deposited in the herbarium of Rzeszów University (RES) and duplicates in the private herbarium of E. Hernik. Their localities are mapped (Fig. 1) according to the Atpol grid square system (ZAJĄC 1978) modified by CIEŚLIŃSKI and FAŁTYNOWICZ (1993).

\section{Results}

Absconditella delutula (Nyl.) Coppins et H. Kilias (Figs. 2 C-E).

This microlichen usually grows on siliceous rocks; it is very rarely found on other substrates, e.g. decaying wood (CZARNOTA and KUKWA 2008). Its thallus is almost invisible and looks like a thin gelatinous film, like other representatives of the genus. 1-septate, ellipsoid to fusiform spores are characteristic of this species, distinguishing it from the similar in general appearance $A$. lignicola, with 3-septate ascospores. Considering the shape and the spore septation A. delutula resembles A. sphagnorum, but in the later case ascospores are smaller. Moreover A. sphagnorum occurs usually in completely different habitats, inhabiting Sphagnum mosses and is found on or close to peat bogs. Similar, 1-septate ascospores and pale, translucent when wet apothecia are also known in the common and widespread Dimerella pineti. However, this species usually grows on the bark of trees or occasionally on humus. A. delutula has only recently been reported quite frequently in Europe (ZIMMERMANN et al. 2011), and is also known from Asia, Australia and Greenland (CZARNOTA and KuKwa 2008).

List of localities: Wyżyna Czestochowska upland, Atpol Fd-17, Przyłubsko village, 50³2' N, $19^{\circ} 36^{\prime}$ E, roadside in Pinus sylvestris forest, on thallus of Peltigera sp., November 7, 2005, leg. E. Hernik 18 (RES; hb. E. Hernik).

\section{Agonimia vouauxii (B. De Lesd.) M. Brand et Diederich (Figs. 2 A-B).}

This species was collected in Poland in the metal-enriched post-mining habitats in Upper Silesia (BIELCZYK 2012, GuZOW-KRZEMIŃSKA et al. 2012). Other reports of A. vouauxii show that this ephemeral species is ecologically tolerant (SCHIFELBEIN et al. 2010, VONDRÁK et al. 2010). A. vouauxii inhabiting Peltigera is reported only by DIEDERICH et al. (2013) from Luxembourg. Among other representatives of the genus, A. vouauxii is distinguished by 2 -spored asci containing ascospores of $47-52 \times 15-20 \mu \mathrm{m}$ and its verrucose to warted, non squamulosae, green thallus. Considering the 2-spored asci, only A. tristicula could be confused with this species, but its ascospores, perithecia and the subsquamules of the thallus are much larger. Another species similar to A. vouauxii, Polyblastia agraria, found directly on clayey soil, has a thin, gelatinous thallus (CEYNOWA-GIEEDON 2001). 
List of localities: Wyżyna Czestochowska upland, Atpol Fd-06, between Rzędkowice and Hucisko villages, $50^{\circ} 34^{\prime} \mathrm{N}, 1^{\circ} 28^{\prime} \mathrm{E}$, on the site of a small fire at the edge of a pine forest, on Peltigera sp., August 1, 2005, leg. E. Hernik 13 (RES); Atpol Fd-07, Kostkowice village, $50^{\circ} 34^{\prime}$ N, $19^{\circ} 35^{\prime}$ E, roadside ditch, on moribund Peltigera didactyla, November 3 , 2005, leg. E. Hernik 14 (RES); Atpol Fd-17, Przyłubsko village, 50`32’ N, 19³6’ E, on Peltigera cf. didactyla over calcareous soil, November 7, 2005, leg. E. Hernik 3a (RES); ibid., roadside ditch, on Peltigera didactyla, August 29, 2005, leg. E. Hernik 10 (RES); ibid., Siedliszowice village near Pilica town, 50³2' N, 1940' E, on Peltigera rufescens, September 5, 2005, leg. E. Hernik 9 (RES); Atpol Fd-26, Srubarnia village, Lachowizna settlement, $50^{\circ} 27^{\prime} \mathrm{N}, 19^{\circ} 30^{\prime} \mathrm{E}$, roadside pine forest, on moribund thallus of Peltigera sp. January 10, 2005, leg. E. Hernik 12 (RES).
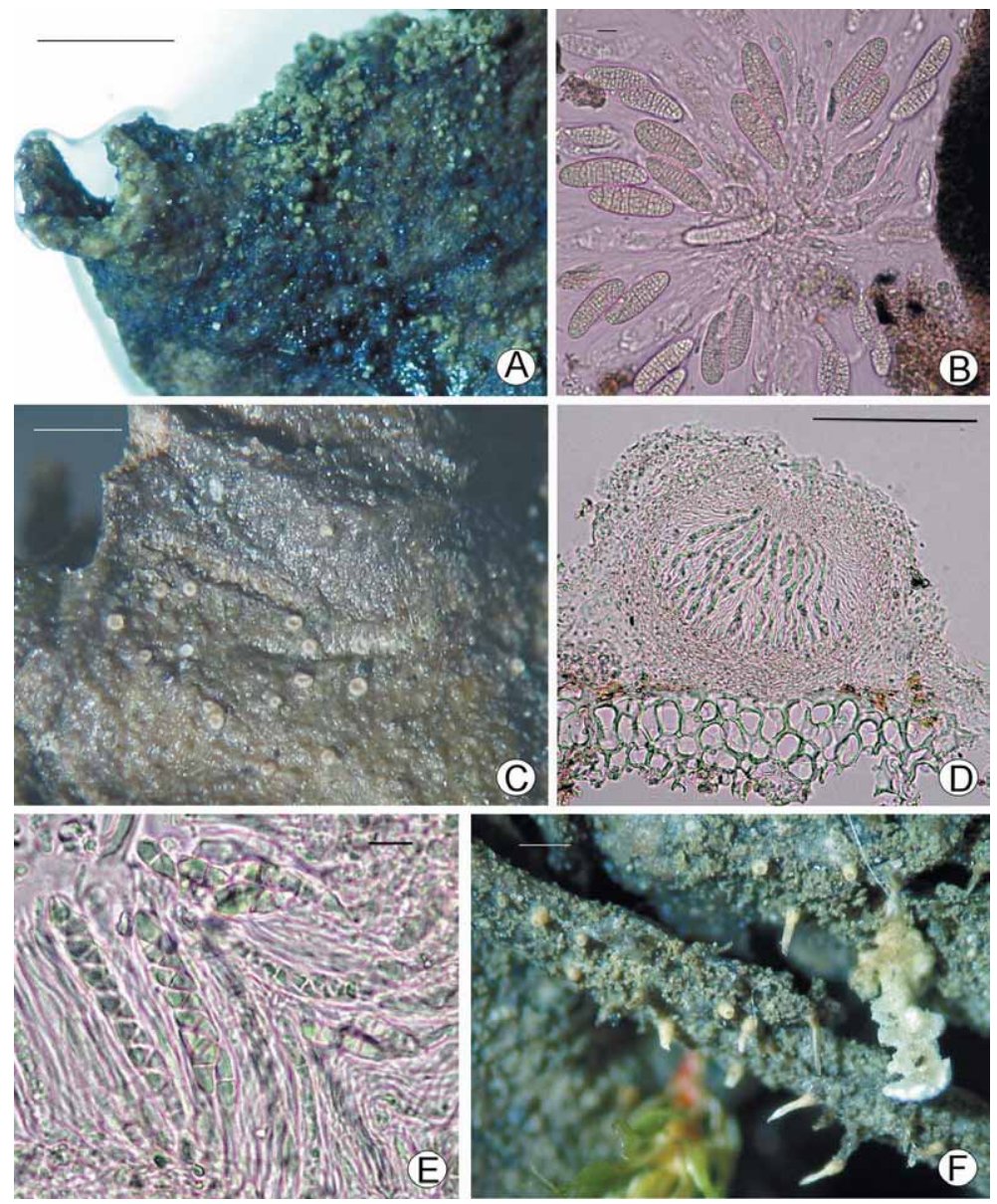

Fig. 2. Peltigericolous lichens: A - habit of Agonimia vouauxii (E. Hernik 14); B - ascospores of A. vouauxii (E. Hernik 9); C - habit of Absconditella delutula (E. Hernik 18); D - apothecial section of A. delutula (E. Hernik 18); E - asci and ascospores of A. delutula (E. Hernik 18); $\mathbf{F}$ - habit of anamorphic stage of Bacidia pycnidiata (partially on plant debris) (E. Hernik 8a). Scale bars: A, C, F- 1 mm; B, E- $10 \mu \mathrm{m}$; D - $100 \mu \mathrm{m}$. 
Bacidia pycnidiata Czarnota et Coppins (Fig. 2F).

This species recently described by Czarnota and Coppins (2006) from the Czech Republic and Poland is currently also known from Belgium (ERTZ et al. 2008), Lithuania (MotiejūNAite et al. 2011), Finland (PyKÄLÄ 2008) and Estonia (SuIJA et al. 2007). In the
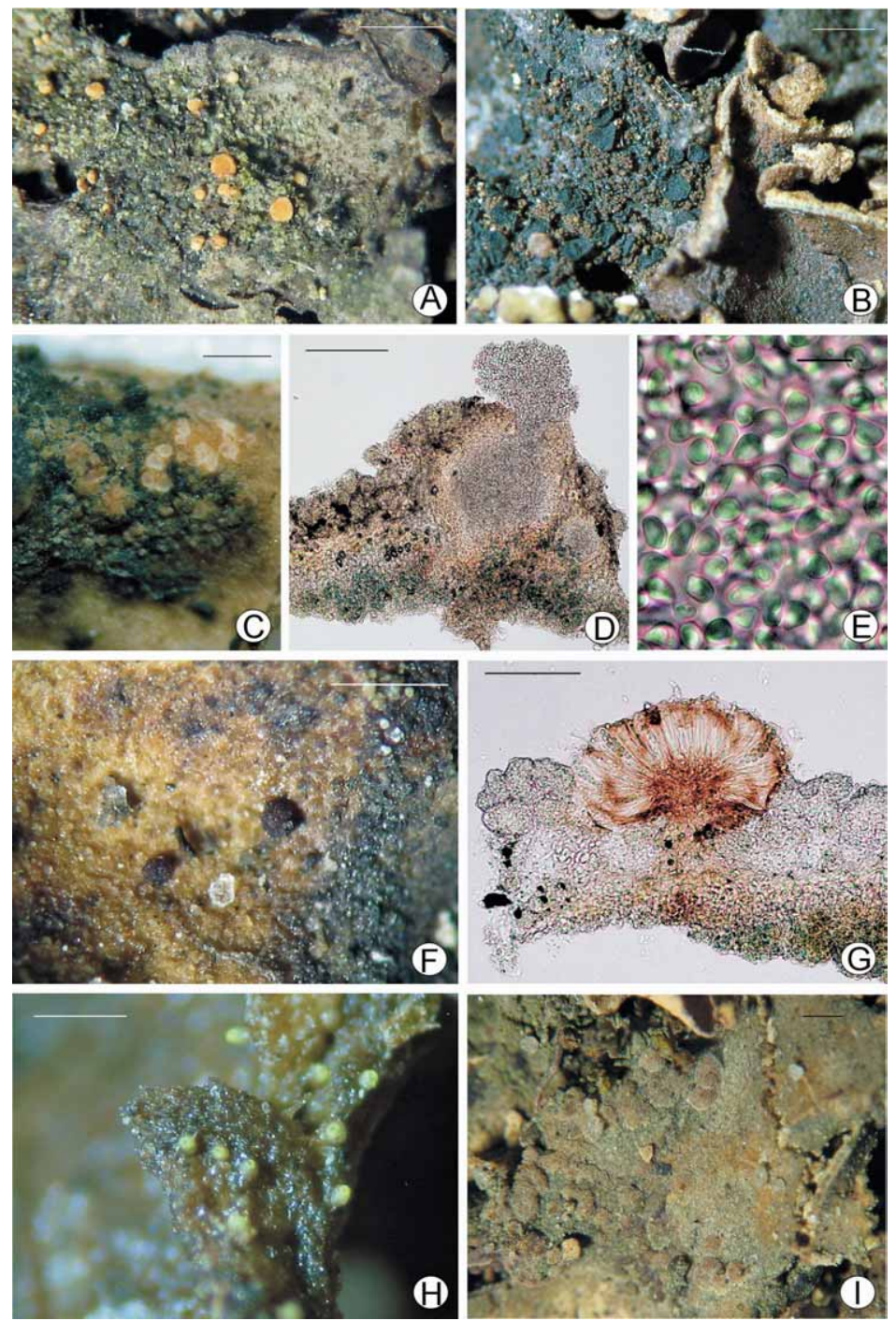

Fig. 3. Peltigericolous lichens: A - habit of Bacidina chloroticula (E. Hernik 17); B - habit of Placynthiella dasaea (E. Hernik 11); C-habit of anamorphic stage of Scutula sp. (E. Hernik 2); D - pycnidial section of Scutula sp. and its Peltigera host (E. Hernik 2); E-mesoconidia of Scutula sp. (E. Hernik 2); F - habit of Steinia geophana (E. Hernik 6); G - apothecial section of S. geophana and its Peltigera host (the apothecium surrounded by goniocysts of Vezdaea retigera) (E. Hernik 6); $\mathbf{H}$ - habit of Thelocarpon epibolum (E. Hernik 4); I-habit of Vezdaea aestivalis (E. Hernik 5). Scale bars: A, B, C, F, H, I-1 mm; D, G-100 $\mu \mathrm{m} ; \mathrm{E}-10 \mu \mathrm{m}$. 
meantime several new localities of B. pycnidiata in central Poland (ŁUBEK 2009, 2012) and the Czech Republic (VoNDRÁK et al. 2010) have been discovered, but samples inhabiting the thalli of Peltigera species have never been shown to date anywhere. Bacidia pycnidiata was recorded in different circumstances, in more or less managed woodlands as well as in old-growth forests, mostly as an epiphyte or inhabiting terricolous and corticolous bryophytes. It is reasonably tolerant to human impact (MoTIEJŪNAITE et al. 2011). Indeed, data presented here, from a strongly industrialized region of Poland and other unpublished author's records on metal-rich wastes, show that B. pycnidiata has a large ecological plasticity. In the studied area, particularly in the Wyżyna Częstochowska upland, this species seems to prefer dry sandy habitats at the edge of pine forests close to natural limestone rocks. Perhaps it is more common elsewhere, but it grows mostly without apothecia, forming long-necked diagnostic pycnidia, usually immersed within green, minutely granular thallus, and more or less straight conidia.

List of localities: Wyżyna Czestochowska upland, Atpol Fd-06, between Rzędkowice and Hucisko villages, $50^{\circ} 34^{\prime} \mathrm{N}, 1^{\circ} 28^{\prime} \mathrm{E}$, close to an electric line at the edge of pine forest, on moribund thallus of Peltigera didactyla, July 12, 2005, leg. E. Hernik 8a-d (RES).

Bacidina chloroticula (Nyl.) Vězda et Poelt (Fig. 3 A).

The identification of several members of Bacidina forming small, pale, orange-pink or beige apothecia (e.g. B. phacodes (Körber) Vězda, B. delicata (Larbal. ex Leight.) V. Wirth et Vězda, B. chloroticula, B. contexta S. Ekman et T. Sprib., B. californica S. Ekman and B. crystalifera $\mathrm{S}$. Ekman) is sometimes very difficult. This is due their non specific diagnostic characters referring to the size of excipular hyphae, the septation and dimensions of their thin, acicular ascospores and conidia and the structure of their thalli. The varying morphology of some of these characters can be considered as some kind of infraspecies variability within most of the above mentioned species depending on their individual ontogeny. For $B$. chloroticula the wide lumina of excipular hyphae resulting in the entirely paraplectenchymatic excipulum are the main diagnostic characters, and, based on this feature, it has been determined here despite the distinct orange apothecia resembling $B$. delicata instead (see Fig. 3 A). Peltigericolous $B$. chloroticula has already been recorded once in Poland by MiąDLIKOWSKA (1999), but on other substrates (plant debris, wood, natural and artificial rocks, sometimes bark of trees and roots) it is commonly reported in Europe, and known also in North America and Asia (COPPINS and APTROOT 2009).

List of localities: Obniżenie Górnej Warty depression, Atpol Ed-94, Dębowiec village, 5041' N, 19 $13^{\circ}$ ' E, on Peltigera canina, November 6, 2005, leg. E. Hernik 19 (RES); Wyżyna Czestochowska upland, Atpol Fd-06, between Rzędkowice and Hucisko villages, 50³4' N, $19^{\circ} 28^{\prime}$ E, roadside pine forest, on moribund thallus of Peltigera cf. didactyla, July 12, 2005, leg. E. Hernik 17 (RES); Garb Tarnogórski hummock, Atpol Fd-16, Kotlina Mitręgi basin, Józefów village near Zawiercie town, by the tributary of Ogrodzieniecki stream to Czarna Przemsza river, 50²7' N, $19^{\circ} 14^{\prime}$ E, by road in spruce forest, on Peltigera cf. didactyla, December 29, 2004, leg. E. Hernik 16a-b (RES; hb. Hernik).

Placynthiella dasaea (Stirt.) Tønsberg (Fig. 3 B).

This is a commonly widespread species in the northern hemisphere growing lignicolous, corticolous or rarely terricolous (HITCH and PURVIS 2009), but only sometimes inhabiting 
thalli of Peltigera. P. dasaea usually grows as a sterile crust forming a granular, green to brown thallus fleetingly reacting $\mathrm{C}+$ red due to the gyrophoric acid. For more taxonomic details and affinities to other taxa see TøNSBERG (1992).

List of localities: Garb Tarnogórski hummock, Atpol Fd-16, Kotlina Mitręgi basin, Józefów village (Fugasówka settlement) near Zawiercie town, by the tributary of Ogrodzieniecki stream to Czarna Przemsza river, under an electric line in pine forest, on thallus of Peltigera sp., December 27, 2004, leg. E. Hernik 1 (RES); Wyżyna Częstochowska upland, Atpol Fd-26, Śrubarnia village, Lachowizna settlement, 50²7’ N, 19³0’ E, roadside pine forest, on moribund thallus of Peltigera sp. January 10, 2005, leg. E. Hernik 11 (RES).

\section{Scutula sp. (Figs. 3 C-E).}

The sample examined here probably represents an undescribed anamorphic mesoconidial state of some peltigericolous species of Scutula, better known as Libertiella. A similar specimen has already been found in N Poland on Peltigera didactyla by M. Kukwa (CZYŻEWSKA and KUKWA 2009), who gave a brief description without any nomenclatural innovation. Our lichenized specimens have well developed, slightly warted, pale green thalli and more or less immersed, obpyriform pycnidia of 120-170 $\mu \mathrm{m}$ width, producing ovoid to almost globose conidia, (3-)3.5-4 × 4-5 $\mu \mathrm{m}$ (Fig. $3 \mathrm{C}-\mathrm{E})$. Upper external parts of pycnidia are slightly brownish with distinctly pale collar around the ostiolum, but usually pycnidia are wide open and concave showing the pale conidial mass and excipulum (Fig. $3 \mathrm{D})$. Then they look like pycnidia strongly damaged by snails. Scutula sp. was found in the company of other peltigericolous lichen-forming fungi: Steinia geophana and Vezdaea retigera.

List of localities: Wyżyna Czestochowska upland, Atpol Fd-07, by the road between Huta Szklana settlement and Pradła village, 50³4' N, 19³9' E, roadside ditch, on moribund thallus of Peltigera cf. didactyla, August 19, 2005, leg. E. Hernik 2a-d (RES; hb. Hernik).

\section{Steinia geophana (Nyl.) Stein (Figs. 3 F-G).}

This usually terricolous worldwide microlichen (FLETCHER et al. 2009) has already been found also to be peltigericolous on Peltigera didactyla by ALSTRUP and LAESSOE (1986) in Denmark, Alstrup and Hawksworth (1990) in Greenland and on Peltigera rufescens in Poland by MiąDLikowska (1999). In the cases included here, besides the more or less moribund thalli of some Peltigera, S. geophana was found also on other substrates such as a humus, plant debris or soil. However, inhabiting Peltigera this lichenized fungus probably plays the role of an additional component (together with its photobiont) in occasional four-biont symbioses (Fig. $3 \mathrm{G}$ ). This relationship may have a parasitic character and finally, S. geophana can grow on a dead thallus of Peltigera. S. geophana mostly resembles some black-coloured species of Micarea, for example $M$. deminuta and $M$. contexta, by its immarginate strongly convex apothecia and a membrane-like, often inconspicuous thallus. This species develops, however, 16-spored asci with almost globose ascospores (Fig. $3 \mathrm{G}$ ), while members of Micarea are permanently 8-spored. For detailed description of S. geophana see FLETCHER et al. (2009). 
List of localities: Wyżyna Częstochowska upland, Atpol Fd-06, between Rzędkowice and Hucisko villages, $50^{\circ} 34^{\prime} \mathrm{N}, 1^{\circ} 28^{\prime} \mathrm{E}$, close to an electric line at the edge of pine forest, on moribund thallus of Peltigera sp., July 12, 2005, leg. E. Hernik 6, 7 (RES); Atpol Fd-07, by the road between Huta Szklana settlement and Pradła village, 50`34' N, 19³9’ E, roadside ditch, on moribund thallus of Peltigera cf. didactyla, August 19, 2005, leg. E. Hernik 20 (RES).

\section{Thelocarpon epibolum Nyl. (Fig. 3 H).}

This perithecioid microlichen was recorded many times in Poland as lichenicolous (CZYŻEWSKA and KUKWA 2009), as well as lignicolous or occasionally overgrowing other substrates (FAŁTYNOWICZ 2003). It usually develops an external, thin, gelatinous thallus with Coccomyxa-algae and is often found on different representatives of Peltigera, but its strong trophic relationship to this lichen host has not been observed. However, more than any other species of the genus, T. epibolum tends to be peltigericolous (KOCOURKOVÁ 2000). There are some differences in ascospore dimensions between specimens determined under the name T. epibolum elsewhere, but due to the lack of molecular support to confirm delimitation of the new taxon, this name is used here. Examined specimens produce ascospores 4-6 $\times 2-2.5 \mathrm{~mm}$, thus they correspond to the type of T. epibolum Nyl. var. epibolum (KoCOURKOVÁ 2000).

List of localities: Obniżenie Górnej Warty depression, Atpol Ed-94, Masłonskie Natalin village, $50^{\circ} 39^{\prime} \mathrm{N}, 19^{\circ} 13^{\prime}$ E, at the edge of pine forest, on Peltigera canina, November 5, 2005, leg. E. Hernik 23 (RES); Wyżyna Czestochowska upland, Atpol Fd-06, between Rzędkowice and Hucisko villages, 50 $34^{\prime}$ N, $19^{\circ} 28^{\prime}$ E, roadside at the edge of pine forest, on moribund thallus of Peltigera didactyla, July 12, 2005, leg. E. Hernik 7 (RES, together with Steinia geophana) and E. Hernik 22a-b (RES); ibid., July 8, 2005, leg. E. Hernik 24 (RES); Atpol Fd-07, Kostkowice village, 50³4’ N, 19³5’ E, roadside ditch, on moribund Peltigera didactyla, November 3, 2005, leg. E. Hernik 15 (RES); by the road between Huta Szklana settlement and Pradła village, 50³4' N, 19³9’ E, roadside ditch, on moribund thallus of Peltigera cf. didactyla, August 19, 2005, leg. E. Hernik 25 (RES); Atpol Fd-17, Przyłubsko village, 50³2’ N, 19³6’ E, roadside ditch, on moribund thallus of Peltigera sp., November 7, 2005, leg. E. Hernik 4 (RES).

Vezdaea aestivalis (Ohlert) Tscherm.-Woess et Poelt (Fig. 3 I).

Vezdaea aestivalis was reported from Poland on the thalli of several species of Peltigera by Miądlikowska and Alstrup (1995), CZARnota and KiszKa (2004) and Czyżewska et al. (2008), however, it is reported only rarely to be peltigericolous. Most often it is found overgrowing bryophytes on the bark of trees, various rocky substrates and on soil. This ephemeral species has a huge ecological plasticity, as it can occur in strongly managed or as well in 'ancient' environments (CZARNOTA and KISZKA 2004). Among other species of the genus Vezdaea, V. aestivalis can be recognized by large (visible without microscope) apothecia, 2-septate ascospores, strongly branched and anastomosed paraphyses entwining individual asci and well developed, non-granular, external thallus.

List of localities: Wyżyna Częstochowska upland, Atpol Fd-07, Kostkowice village, $50^{\circ} 34^{\prime} \mathrm{N}, 19^{\circ} 35^{\prime}$ E, at the edge of pine forest, on Peltigera sp., November 4, 2005, leg. E. Hernik 5, 5a (RES; hb. Hernik). 


\section{Vezdaea retigera Poelt et Döbbeler}

This toxitolerant ephemeral species is frequently found in Western Europe and North America in metal-enriched habitats on base-rich grounds, as well as on terricolous bryophytes often in post-mining areas or on waste heaps (CHAMBERS and PURVIS 2009). It was already recorded on some Peltigera (PALICE 1999, Alstrup et al. 2004, Chambers and PurVIS 2009), also in Poland (CZYŻEWSKA and KUKWA 2009); however, in this country it is regarded as rather rare (CZARNOTA and KUKWA 2009). Surely, V. retigera is more frequent especially in post-industrial sites, but overlooked or undercollected as it usually forms only sterile thalli composed of minutely granular pale green and translucent goniocysts. In the case of specimens mentioned in this paper, V. retigera is a peltigericolous lichen-forming species mostly accompanied with Steinia geophana.

List of localities: Wyżyna Czestochowska upland, Atpol Fd-07, by the road between Huta Szklana settlement and Pradła village, 50³4' N, 19³9' E, roadside ditch, on moribund thallus of Peltigera cf. didactyla, August 19, 2005, leg. E. Hernik 2a-b,d (RES, together with Scutula sp.); Atpol Fd-06, between Rzędkowice and Hucisko villages, 50 34' N, $19^{\circ} 28^{\prime}$ E, on small post-fire place at the edge of pine forest, on Peltigera sp., August 1, 2005, leg. E. Hernik 26a, b (RES).

\section{Discussion}

The investigation carried out in contaminated industrialized areas of southern Poland revealed ten lichenized fungi inhabiting thalli of several terricolous representatives of the genus Peltigera. Most of them have already been reported as peltigericolous lichens, but the recently described Bacidia pycnidiata has been found on this kind of substrate for the first time. This shows its larger ecological plasticity, contradicting the previous state of knowledge. Almost all species belong to the group of ephemeral microlichens or early colonizers. Therefore, they are often overlooked. They all are possibly much more common in the study area, but except for the probably new member of the genus Scutula, rather confined to other substrates, e.g. plant debris, decaying wood, humus, siliceous pebbles and soil. Thus they should be regarded as occasional lichenicolous lichens, mostly commensal but in the course of time some of them, e.g. Steinia geophana may become even parasitizing. The undescribed Scutula, found here in its second locality in Poland, however seems to be obligatorily peltigericolous.

\section{Acknowledgements}

A part of this study was financially supported by the University of Rzeszów task grant No. WBR/KA/DS/5/2013.

\section{References}

Alstrup, V., Laessoe, T., 1987: A late-season parasitic flora on Peltigera didactyla at Allerod, Denmark. Graphis Scripta 1, 56-57.

Alstrup, V., Hawksworth, D., 1990: The lichenicolous fungi of Greenland. Meddelelser om Grønland, Biosience 31, 1-90. 
Alstrup, V., Svane, S., Søchting, U., 2004: Additions to the lichen flora of Denmark VI. Graphis Scripta 15, 45-50.

BIELCZYK, U., 2012: Lichens of zinc-lead post-mining areas in the Olkusz region - state of preservation, threats and needs for protection. In: LIPNICKI, L. (ed.), Lichen protection protected lichen species, 119-128. Sonar Literacki, Gorzów Wielkopolski.

CANDAN, M., HAlici, M. G., TÜRK, A. Ö., 2010: New records of peltigericolous fungi from Turkey. Mycotaxon 111, 149-153.

Ceynowa-GieŁdon, M., 2001: Calciphilous terricolous lichens in Kujawy (In Polish). Wydawnictwo Uniwersytetu Mikolaja Kopernika, Torun.

Chambers, S. P., Purvis, O. W., 2009: Vezdaea Tscherm.- Woess Poelt (1976). In: Smith, C. W., Aptroot, A., Coppins, B. J., Fletcher, A., Gilbert, O. L., James, P. W., Wolseley, P. A. (eds.), The lichens of Great Britain and Ireland, 958-961. The British Lichen Society, London.

CieŚliński, S., FAŁTYNOWiCZ, W., 1993: Note from editors. Atlas of the geographical distribution of lichens in Poland, 7-8. W. Szafer Institute of Botany, Polish Academy of Sciences, Kraków.

Coppins, B. J., 1987: The genus Vezdaea in the British Isles. Lichenologist 19, 167-176.

Coppins, B. J., Aptroot A., 2009: Bacidia De Not. (1846). In: Smith, C. W., Aptroot, A., Coppins, B. J., Fletcher, A., Gilbert, O. L., James, P. W., Wolseley, P. A. (eds.), The lichens of Great Britain and Ireland, 189-207. The British Lichen Society, London.

CZARnOTA, P., 2009: Lichen symbioses in the light of relationships between mycobionts and fotobionts (In Polish). Kosmos. Problemy Nauk Biologicznych 58, 229-248.

Czarnota, P., Kiszka, J., 2004: Vezdaea aestivalis (Ohlert) Tsch.-Woess \& Poelt. In: BielCZYK, U., CieŚlińsKi, S., FAŁTYNOWiCZ, W. (eds.), Atlas of the geographical distribution of lichens in Poland 4, 107-110. W. Szafer Institute of Botany Polish Academy of Sciences, Kraków.

CZArnota, P., Coppins, B. J., 2006: A new Bacidia with long-necked pycnidia from central Europe. Lichenologist 38, 407-410.

Czarnota, P., Kukwa, M., 2008: Contribution to the knowledge of some poorly known lichens in Poland. I. The genus Absconditella. Folia Cryptogamica Estonica 44, 1-7.

Czarnota, P., Kukwa, M., 2009: Contribution to the knowledge of some poorly known lichens in Poland. III. Trapelia corticola and the genus Vezdaea. Folia Cryptogamica Estonica 46, 25-31.

Czyżewska, K., Hachulka, M., ŁubeK, A., Zaniewski, P., 2008: Distribution of some lichenicolous fungi in Poland. II. Acta Mycologica 43, 193-206.

CZyŻEwsKA, K., KukwA, M., 2009: Lichenicolous fungi of Poland. A catalogue and key to species. W. Szafer Institute of Botany, Polish Academy of Sciences, Kraków.

Diederich, P., Ertz, D., Stapper, N., Sérusiaux, E., van den Broeck, D., van den Boom, P., RIES, C., 2013: The lichens and lichenicolous fungi of Belgium, Luxemburg and northern France. Retrieved February 14, 2013 from http://www.lichenology.info

Ertz, D., Diederich, P., Brand, A. M., van den Boom, P., SÉRusiaux, E., 2008: New or interesting lichens and lichenicolous fungi from Belgium, Luxembourg and northern France, XI. Bulletin de la Societe des Naturalistes Luxembourgeois 109, 35-51. 
FAŁTYNOwicz, W., 2003: The lichens, lichenicolous and allied fungi of Poland. An annotated checklist. In: MIREK, Z. (ed.), Biodiversity of Poland 6, 1-435. W. Szafer Institute of Botany Polish Academy of Sciences, Kraków.

Fletcher, A., Aptroot, A., Purvis, O. W., 2009: Steinia Körb. (1873). In: Smith, C. W., Aptroot, A., Coppins, B. J., Fletcher, A., Gilbert, O. L., James, P. W., Wolseley, P. A. (eds.), The lichens of Great Britain and Ireland, 856. The British Lichen Society, London.

Guzow-Krzemińska, B., Halda, J. P., Czarnota, P., 2012: A new Agonimia from Europe with a flabelliform thallus. Lichenologist 44, 55-66.

HAWKSWORTH, D. L., 1988: The variety of fungal-algal symbioses, their evolutionary significance and the nature of lichens. Botanical Journal of the Linnean Society 96, 3-20.

Hawksworth, D. L., MiądLikowska, J., 1997: New species of lichenicolous fungi occurring on Peltigera in Ecuador and Europe. Mycological Research 101, 1127-1134.

Hitch, C. J. B., Purvis, O. W., 2009: Placynthiella Elenkin (1909). In: Smith, C. W., Aptroot, A., Coppins, B. J., Fletcher, A., Gilbert, O. L., James, P. W., Wolseley, P. A. (eds.), The Lichens of Great Britain and Ireland, 712-714. The British Lichen Society, London.

InDEX FunGORUM, 2013. Retrieved March 12, 2013 from http://indexfungorum.org.

KocourkovÁ, J., 2000: Lichenicolous fungi of the Czech Republic. (The first commented checklist). Acta Musei Nationalis Pragae, Series B, Historia Naturalis 55, 59-169.

KoŁodzIEJeK, J., 2001a: Potentilla silesiaca Uechtr. Pieciornik slaski. In: KaZMiERCZAKowA, R., ZARZYCKI, K. (eds.), Polish red data book of plants. Pteridophytes and flowering plants. 197-198. W. Szafer Institute of Botany and Institute of Nature Conservation, Polish Academy of Sciences, Kraków.

KoŁodziejeK, J., 2001b: Mursh-meadow vegetation in the mine-devastated area of the Częstochowa Ore District (In Polish). Wydawnictwo Uniwersytetu Lódzkiego, Lódz.

Kondracki, W., 2000: The regional geography of Poland (In Polish). Wydawnictwo Naukowe PWN, Warszawa.

KüMmerling, H., Alstrup, V., 1992: Some peltigericolous fungi, mainly from Scandinavia. Graphis Scripta 3, 120-121.

Kwiatkowska, A., 2001: Cochlearia polonica Fröhlich. Warzucha polska. In: KAZMIERCZAKowa, R., ZARZYCKI, K. (eds.), Polish red data book of plants. Pteridophytes and flowering plants, 166-168. W. Szafer Institute of Botany and Institute of Nature Conservation, Polish Academy of Sciences, Kraków.

ŁubeK, A., 2009: New records of lichens from the Polish uplands. Acta Mycologica 44, 275-282.

ŁuBEK, A., 2012: A profile of lichen diversity down the trunk of common ash (Fraxinus excelsior) highlights its importance in maintaining lichen species diversity In the Oleszno reserve (Przedborski Landscape Park). Forest Research Papers 73, 23-32.

Martinez, M., 1999: Taxonomía del género Peltigera Willd. (Ascomycetes Liquenizados) en la Península Ibérica y studio de sus hongos liquenícolas. Ruizia 15, 4-200.

Martinez, I., HAfEllner, J., 1998: Lichens and lichenicolous fungi on Peltigerales in the Iberian Peninsula and Canary Islands. Mycotaxon 69, 271-310. 
Miądlikowska, J., 1999: The genus Peltigera (Peltigerales, Ascomycota) in Poland in the light its modern systematic (In Polish). PhD Thesis, University of Gdansk.

MiądlikowsKa, J., Alstrup, V., 1995: Some peltigericolous fungi and lichens mainly from Poland. Graphis Scripta 7, 7-10.

MireK, Z., 2001: Galium cracoviense - Przytulia malopolska. In: KAZMIERCZAKOwA, R., ZARZYCKI, K. (eds.), Polish red data book of plants. Pteridophytes and flowering plants, 306-308. W. Szafer Institute of Botany and Institute of Nature Conservation, Polish Academy of Sciences, Kraków.

Motiejūnaite, J., Brackel, W. V., StončIus, D., Preikša, Ž., 2011: Contribution to the Lithuanian flora of lichens and allied fungi. III. Bothanica Lithuanica 17, 39-46.

NowAK, J., 1959: Verrucaria polonica n. sp., Lichen de Polonia meridionali (Verrucaria polonica n. sp. Fragmenta Floristica et Geobotanica 5, 155-163.

PALICE, Z., 1999. New and noteworthy records of lichens in the Czech Republic. Preslia 71, 289-336.

PuolasmaA, A., Toivanen, A., Marsh, T., Huhtinen, S., Stenroos, S., 2012: Peltigericolous fungi from Finland - three genera and six species new to Finland. Karstenia 52, $1-48$.

PYKÄLÄ, J., 2008: Additions to the lichen flora of Finland. III. Graphis Scripta 20, 19-27.

Schiefelbein, U., De Bruyn, U., Dolnik, C., Stolley, G., Neumann, P., 2010: New or interesting records of lichen-forming and lichenicolous fungi from northern Germany. Herzogia 23, 85-91.

Suija, A., LePPIK, E., RAndlane, T., ThOR, G., 2007: Lichens and lichenicolous fungi. Folia Cryptogamica Estonica 43, 73-76.

TønsberG, T., 1992: The sorediate and isidiate, corticolous, crustose lichens in Norway. Sommerfeltia 14, 1-331.

URBISZ, A., 2004: Synopsis of the vascular plant flora of the Kraków-Częstochowa Uland (In Polish). Wydawnictwo Uniwersytetu Slaskiego, Katowice.

Vondrák, J., Halda, J. P., MalǐčEK, J., Müller, A., 2010: Lichens recorded during the spring bryo-lichenological meeting in Chriby Mts (Czech Republic), April 2010. Bryonora 45, 36-42.

Vondrák, J., Merkulova, O., Redchenko, O., 2010: Several noteworthy lichens found in the foothills of the Šumava Mts, South Bochemia, Czech Republic. Bryonora 45, 31-35.

ZAJĄC, A., 1978: Atlas of distribution of vascular plants in Poland (ATPOL). Taxon 27, 481-484.

Zimmermann, D.-G., Bültmann, H., Guderley, E., 2011: Neue und bemerkenswerte Funde von Flechten und flechtenbewohnenden Pilzen in Nordrhein-Westfalen I. Abhandlungen aus dem Westfälischen Museum für Naturkunde 73, 1-64. 